\title{
PENGARUH MODEL PEMBELAJARAN BERBASIS MASALAH BERBANTUAN MACROMEDIA FLASH TERHADAP HASIL BELAJAR SISWA KELAS XI SMA St. YOSEPH MEDAN T.P 2014/2015
}

\author{
Angela Mutia dan Sondang R. Manurung \\ Jurusan Fisika FMIPA Universitas Negeri Medan \\ angelamutia@ymail.com
}

\begin{abstract}
ABSTRAK
Penelitian ini bertujuan untuk mengetahui pengaruh model pembelajaran berbasis masalah untuk meningkatkan hasil belajar fisika siswa pada materi fluida dinamis di kelas XI SMA St. Yoseph Medan T.P 2014/2015.Jenis penelitian ini adalah quasi eksperimendengan desain control group pretest-posttest. Populasi dalam penelitian adalah seluruh siswa kelas XI SMA St. Yoseph Medan. Pengambilan sampel dilakukan dengan cara cluster random sampling dengan mengambil 2 kelas yaitu kelas XI IPA 1 sebagai kelas eksperimen dan kelas XI IPA 2 sebagai kelas kontrol dengan masing-masing berjumlah 32 orang. Instrumen yang digunakan untuk mengetahui hasil belajar siswa adalah tes hasil belajar berbentuk pilihan berganda dengan jumlah 20 soal yang sudah divalidasi dan lembar penilaian afektif serta psikomotorik siswa. Berdasarkan hasil uji hipotesis menggunakan uji beda (uji-t) diperoleh ada pengaruh signifikan dari penerapan model pembelajaran berbasis masalah berbantuan macromedia flash terhadap hasil belajar siswa pada materi fluida dinamis di kelas XI SMA St. Yoseph Medan T.P 2014/2015.
\end{abstract}

Kata kunci : pembelajaran berbasis masalah,macromedia flash

\begin{abstract}
This research aimed is to know the effect of problem based learning models to improve learning outcomes physics in Dynamics Fluid in class XI SMA St. Yoseph of Medan Academic Year 2014/2015. This research is a quasi experiment study with control group pretest-posttest design. The population in this research is the whole student in class XI SMA St. Yoseph of Medan. Technique sampling istaken for 2 classes are determined by cluster random sampling, is class XI IPA 1 as a classroom experiment and class XI IPA 2 as a control experiment and each class consisting of 32 students. The instrument for collecting data learning outcomes of the students is multiple choice test, there are 20 items that has been vaidated and affective evaluating sheet and also psychomotoric evaluating sheet. From the hypothesis test using different test ( $t$-test) obtained that is significant effect from using problem based learning model with macromedia flash toward learning outcomes of student in subject Dynamic Fluid in class XI in SMA St. Yoseph of Medan Academic Year 2014/2015.
\end{abstract}

Keywords : problem based learning, macromedia flash 


\section{PENDAHULUAN}

Pendidikan adalah salah satu bentuk perwujudan kebudayaan manusia yang dinamis dan sarat perkembangan. Oleh karena itu, perubahan atau perkembangan pendidikan adalah hal yang memang seharusnya terjadi. Perubahan dalam arti perbaikan pendidikan pada semua tingkat perlu terus-menerus dilakukan sebagai antisipasi kepentingan masa depan. Proses kegiatan belajar mengajar di sekolah merupakan kegiatan yang sangat pentinguntuk meningkatkan kualitas pendidikan. Kegiatan ini merupakan suatu proses yang mengandung serangkaian perbuatan guru dan siswa atas dasar hubungan timbal balik. Interaksi atau hubungan timbal balik dalam peristiwa belajar- mengajar berupa interaksi edukatif, dikarenakan kegiatan belajar mengajar yang dilakukan diarahkan untuk mencapai tujuan tertentu yang telah dirumuskan sebelum pengajaran dilakukan. Guru dengan sadar merencanakan kegiatan pengajarannya secara sistematis dengan memanfaatkan segala sesuatunya guna kepentingan pengajaran. Melalui proses kegiatan belajar mengajar yang optimal diharapkan tujuan pendidikan nasional dapat tercapai.

Berdasarkan hasil observasi berupa wawancara dengan seorang guru fisika, beliau mengatakan bahwa hanya beberapa siswa saja yang menyukai pelajaran fisika terlihat dari hasil belajar siswa yang masih rendah dengan kata lain masih di bawah KKM yaitu 75. Hasil dari angket yang disebarkan kepada 32 siswa diperoleh hanya $18,75 \%$ yang menyukai pelajaran fisika, $43,75 \%$ menyatakan pelajaran fisika sulit dan kurang menarik (Mutia, 2015).

Hal ini didukung dengan cara mengajar guru yang hanya mencatat, membahas contoh soal, kemudian latihan mengerjakan soal dan memberikan tugas rumah. Dengan kata lain model yang digunakan kurang bervariasi karena guru sudah merasa nyaman mengajar dengan pembelajaran yang seperti biasanya yang masih menitikberatkan pada penghafalan rumus fisika, sebab jika harus berganti-ganti model saat mengajar guru merasa tidak efesien dan efektif dalam menggunakan waktu dan harus mengelola kelas dengan sangat baik agar tidak terjadi keributan saat proses belajar mengajar serta sarana dan prasarana yang masih kurang lengkap khususnya pada laboratorium.

Berdasarkan hal di atas, perlu diterapkan suatu perubahan dimulai dari perubahan model pembelajaran dari model pembelajaran yang lazim diterapkan di sekolah. Model yang dipilih adalah model yang mampu meningkatkan hasil belajar siswa. Salah satu alternatif model pembelajaran yang memungkinkan diterapkan adalah model pembelajaran berbasis masalah (PBM). Model PBM merupakan pendekatan yang efektif untuk pengajaran proses berpikir tingkat tinggi (Trianto, 2011). Pembelajaran PBM dikembangkan untuk membantu siswa mengembangkan kemampuan berpikir, pemecahan masalah dan keterampilan intelektual, belajar berbagai peran orang dewasa melalui perlibatan mereka dalam pengalaman nyata dan menjadi pebelajar yang otonom dan mandiri. Menurut Arends (2012), model PBM merupakan suatu pendekatan pembelajaran dimana siswa mengerjakan permasalahan yang autentik dengan maksud untuk menyusun pengetahuan mereka sendiri, mengembangkan inkuiri dan keterampilan berpikir tingkat lebih tinggi, mengembangkan kemandirian dan percaya diri. Pembelajaran ini membantu siswa untuk memproses informasi yang sudah jadi dalam benaknya dan menyusun pengetahuan mereka sendiri tentang dunia sosial dan sekitarnya. Pembelajaran ini cocok 
untuk mengembangkan pengetahuan dasar maupun kompleks.

Penerapan Model pembelajaran PBM sudah pernah diteliti oleh beberapa peneliti sebelumnya, seperti Hermanto (2013) yang menerapkan model PBM di SMA N 1 Sei Bingai pada materi pokok Listrik Dinamis diperoleh nilai pretes kelas eksperimen 41,79 setelah dilakukan perlakuan dengan model PBM diperoleh nilai postes 65,32 . Menurut hasil penelitian Pohan (2013) yang menerapkan model PBM di SMP N 5 Pematang Siantar pada materi pokok Listrik Dinamis diperoleh nilai rata-rata pretes kelas eksperimen 35,29 setelah diberi perlakuan dengan model PBM maka hasil belajar fisika siswa meningkat menjadi 60,43. Berdasarkan hasil kedua peneliti ini diketahui bahwa ada pengaruh yang signifikan antara model pembelajaran PBM terhadap hasil belajar.

Model PBM juga pernah diterapkan oleh Situmorang (2014) di SMA RK Deli Murni Deli Tua pada materi pokok Listrik Dinamis diperoleh rata-rata nilai pretes kelas eksperimen 20,45 setelah diberi perlakuan dengan model PBM hasil belajar siswa meningkat dengan nilai rata-rata postes 52,65. Keberhasilan penerapan model PBM juga didukung oleh penelitian yang dilakukan oleh Selcuk (2010) dengan hasil yang diperolehnya yaitu bahwa hasil postes siswa yang belajar dengan menggunakan model pembelajaran berbasis masalah lebih baik dibandingkan dengan hasil postes siswa yang belajar dengan model pembelajaran konvensional.

Kelemahan dari beberapa peneliti di atas adalah tidak menggunakan media dalam pembelajaran. Media dalam pembelajaran dibutuhkan sebagai salah satu sumber belajar yang membantu penyampaian informasi demi tercapainya tujuan dari pembelajaran yang dilakukan. Hal ini sejalan dengan pendapat Rossi dan Breidle (Sanjaya, 2011), yang mengemukakan bahwa media pembelajaran adalah seluruh alat dan bahan yang dapat dipakai untuk mencapai tujuan pendidikan seperti radio, televisi, buku, koran, majalah dan sebagainya. Media itu adalah keseluruhan yang membantu penyampaian informasi dari pendidik kepada siswa. Salah satu contoh media yang dapat digunakan dalam proses pembelajaran adalah media animasi dengan software Macromedia Flash Pro 8. Media animasi Macromedia Flash Pro 8 memungkinkan proses belajar mengajar lebih menarik karena adanya tampilan berupa animasi atau gambar bergerak dari materi yang akan dipelajari.

Berdasarkan uraian di atas, tujuan dari penelitian ini adalah untuk mengetahuipengaruh model pembelajaran berbasis masalah berbantuan macromedia flashterhadap hasil belajar siswa kelas XI SMA St. Yoseph T.P 2014/2015.

\section{METODE PENELITIAN}

Penelitian dilaksanakan di SMA St. Yoseph Medan yang beralamatkan di Jln. Flamboyan Raya No. 139 Medan. Waktu penelitian yaitu pada semester II tahun pelajaran 2014/2015, tepatnya di bulan April 2015.

Populasi dalam penelitian ini adalah semua siswa-siswi kelas XI SMA St. Yoseph Medan pada semester genap T.P. 2014/2015. Dengan menggunakan teknik clusterrandom sampling, diperolehsampel dari populasi sebanyak 2 kelas. Kelas eksperimen adalah kelas XI IPA 1 yang diberi perlakuan menggunakan model pembelajaran berbasis masalah dan sebagai kelas kontrol adalah kelas XI IPA 2 yang dibelajarkan menggunakan pembelajaran konvensional, masingmasing sampel berjumlah 32 orang.

Jenis penelitian ini adalah quasi eksperimen dengan desain penelitian control group pretest-posttest. Desain penelitian ini ditunjukkan pada Tabel 1. 
Tabel 1. Control Group Pretest-Posttest Design (Arikunto, 2012)

\begin{tabular}{|l|c|c|c|}
\hline \multicolumn{1}{|c|}{ Grup } & $\begin{array}{c}\text { Pre- } \\
\text { tes }\end{array}$ & $\begin{array}{c}\text { Perla- } \\
\text { kuan }\end{array}$ & $\begin{array}{c}\text { Pos- }^{-} \\
\text {tes }\end{array}$ \\
\hline Eksperimen & $X_{1}$ & $P_{1}$ & $X_{2}$ \\
Kontrol & $Y_{1}$ & $P_{2}$ & $Y_{2}$ \\
\hline
\end{tabular}

Keterangan:

$X_{1}=$ Pemberian tes awal (pretes) dari subjek kelas eksperimen

$Y_{1}=$ Pemberian tes awal (pretes) dari subjek kelas kontrol

$P_{1}=$ Pembelajaran menggunakan model pembelajaran berbasis masalahberbantuan macromedia flash

$P_{2}=$ Pembelajaran menggunakan model pembelajaran konvensional.

$X_{2}=$ Pemberian tes akhir (postes) dari subjek kelas eksperimen

$Y_{2}=$ Pemberian tes akhir (postes) dari subjek kelas kontrol

Penelitian ini menggunakan analisis N-Gain.Gain adalah selisih antara postes dan pretes, gain menunjukkan peningkatan pemahaman konsep atau penguasaan konsep siswa setelah pembelajaran dilakukan.Gain score ternormalisasi dapat dihitung dengan rumus berikut.

$$
<g>=\frac{\%<S_{f}>-\%<S_{i}>}{100-\%<S_{i}>}
$$

dimana $<S_{f}>$ adalah final score/post-test (nilai akhir) dan $<S_{i}>$ adalah initial score/pre-test (nilai awal).

Tingkat perolehan gain score ternormalisasi $(g)$ dikategorikan dalam Tabel 2.

Tabel 2. Kategori Tingkat Perolehan Gain Score(Hake, 1998)

\begin{tabular}{|l|c|}
\hline \multicolumn{1}{|c|}{ Interval Nilai } & Kategori \\
\hline$g \geq 0,70$ & Tinggi \\
$0,30 \leq g<0,70$ & Sedang \\
$g<0,30$ & Rendah \\
\hline
\end{tabular}

\section{HASIL DAN PEMBAHASAN Hasil Penelitian}

Kedua kelas diberikan pretes (tes kemampuan awal)pada awal penelitian diperoleh hasil pretes pada kelas eksperimen dengan nilai terendah 10 , nilai tertinggi 45 , nilai rata-rata 22,97 dan simpangan baku 8,02 , dan pada kelas kontrol diperoleh nilai terendah 0 dan nilai tertinggi 30 dengan nilai ratarata 15,16 dan simpangan baku 8,37.Untuk lebih jelasnya, perbandingan hasil pretes kelas eksperimen dan kelas kontrol dapat dilihat pada diagram batang pada Gambar 1.

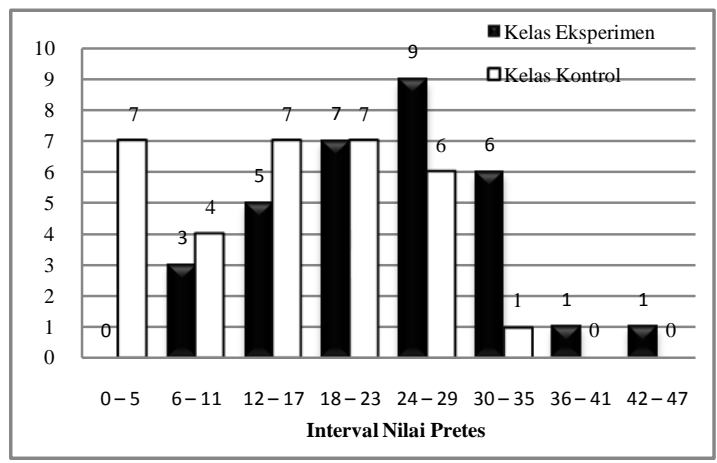

Gambar 1. Diagram Batang Data Pretes Kelas Eksperimen dan Kelas Kontrol

Setelah pretes dilakukan, maka selanjutnya dilaksanakan pembelajaran pada masing-masing kelas yaitu kelas kontrol diajarkan dengan model pembelajaran konvensional sedangkan kelas eksperimen diajarkan dengan model pembelajaran berbasis masalah.

Setelah melakukan seluruh pertemuan dalam kegiatan belajar mengajar dengan waktu selama tiga pertemuan, maka dilakukan postes dengan menggunakan instrument yang sama dengan saat pretes dilakukan. Berdasarkan data hasil penelitian postes pada kelas eksperimen diperoleh nilai terendah 60, nilai tertinggi 95 , nilai rata-rata 83,75 dan simpangan baku 10,93. Pada kelas kontrol diperoleh nilai terendah 60 dan nilai tertinggi 90 dengan nilai rata-rata 
77,81 dan simpangan baku 10,85. Hasil postes ditunjukkan pada Gambar 2.

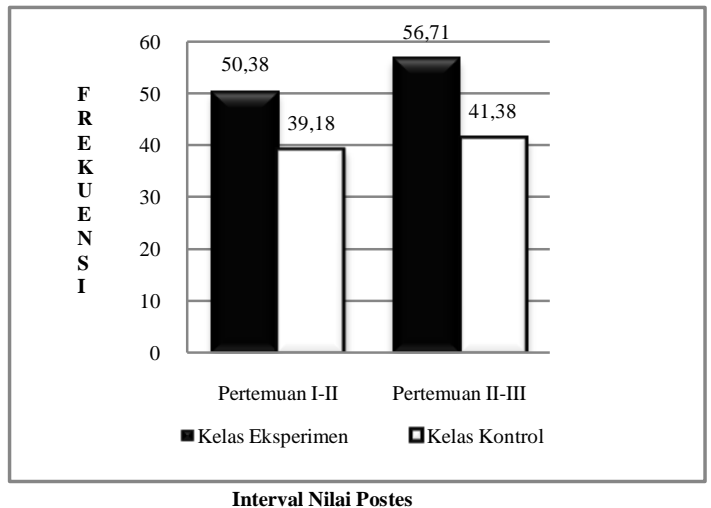

Gambar 2. Diagram Batang Data Postes Kelas Eksperimen dan Kelas Kontrol

Berdasarkan data pretes dan postes yang diperoleh selama penelitian dilakukan, maka dapat dilihat peningkatan kemampuan siswa dengan menggunakan analisis N-Gain. Hasil perhitungan peningkatan hasil belajar (kognitif) dapat dilihat pada Gambar 3.

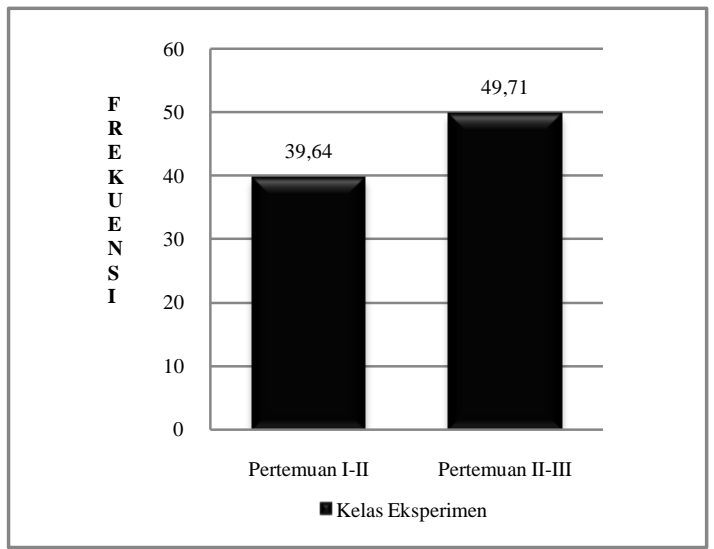

Gambar 3. Diagram Batang Data Postes dan Pretes Kelas Eksperimen dan Kelas Kontrol

Dapat dilihat dari Gambar 3 bahwa terjadi peningkatan kemapuan siswa dalam menyerap pelajaran yang disampaikan oleh guru.

Selama melakukan kegiatan belajar mengajar, peneliti juga menilai sikap (afektif) dari siswa yang berada pada masing-masing kelas, sedangkan untuk penilaian keterampilan (psikomotorik) hanha dilakukan pada kelas eksperimen. Adapun untuk hasil dari penilaian afektif masing-masing kelas dapat dilihat pada Gambar 4.

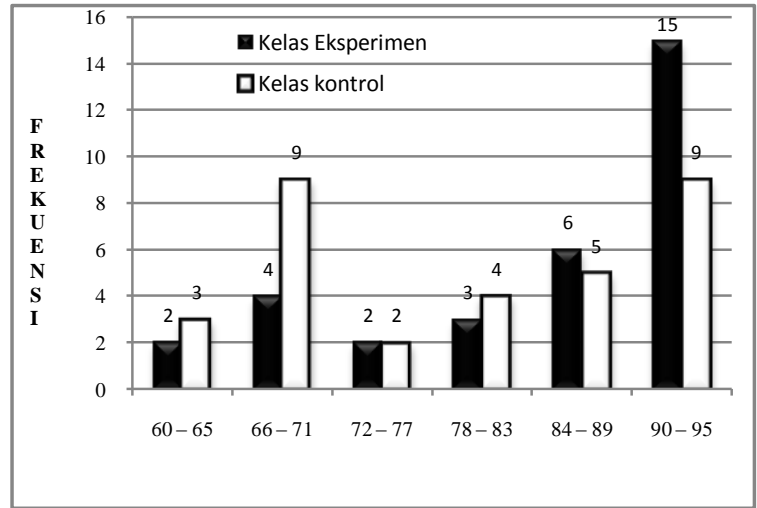

Gambar 4. Diagram Batang Data Penilaian Afektif Kelas Eksperimen dan Kelas Kontrol

Hasil dari penilaian afektif siswa menunjukkan peningkatan dalam tiap pertemuannya. Sama halnya dengan penilaian afektif, penilaian psikomotorik juga mengalami peningkatan. Untuk penilaian psikomotorik hanya dilakukan pada kelas eksperimen. Adapun hasil penilaian psikomotirk dapat dilihat pada Gambar 5.

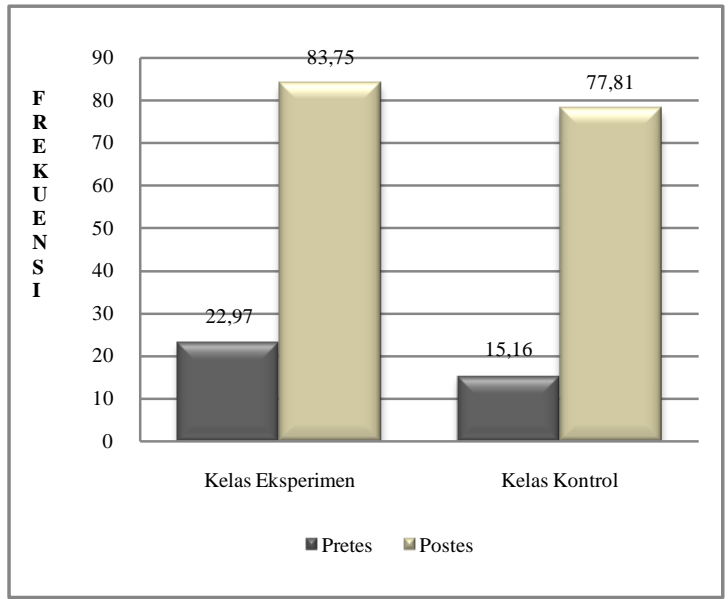

Gambar 5. Diagram Batang Data Penilaian Psikomotorik Kelas Eksperimen

\section{Pembahasan Hasil Penelitian}

Hasil penelitian menunjukkan bahwa ada pengaruh model pembelajaran berbasis masalah dalam meningkatkan hasil belajar siswa pada materi fluida dinamis di kelas XI Semester II SMA St. Yoseph Medan. 
Hal ini dilihat dari perbedaan hasil belajar dan hasil penilaian afektif serta psikomotorik antara kelas eksperimen dengan kelas kontrol.Hasil belajar siswa pada kelas eksperimen yang diberikan perlakuan dengan menerapkan model pembelajaran berbasis masalah berbeda denganhasil belajar siswa kelas kontrol yang diajarkan dengan model pembelajaran konvensional.

Kemampuan akhir siswa dapat diketahui dengan memberikan postes terhadap kedua kelas. Hasil belajar yang diperoleh adalah nilai rata-rata hasil belajar untuk kelas eksperimen adalah 83,75 sedangkan untuk kelas kontrol adalah 77,81. Berdasarkan data tersebut, dapat disimpulkan bahwa nilai rata-rata postes kelas eksperimen lebih tinggi daripada nilai rata-rata postes kelas kontrol. Kriteria pengujian untuk data postes diperoleh thitung $>t_{\text {tabel }}$ yaitu $2,18>1,67$ artinya $\mathrm{H}_{0}$ ditolak dan Ha diterima maka nilai hasil belajar siswa kelas eksperimen lebih besar dari pada kelas kontrol, sehingga dapat disimpulkan bahwa ada pengaruh model pembelajaran berbasis masalah berbantuan macromedia flash dalam meningkatkan hasil belajar siswa kelas XI SMA St. Yoseph Medan T.P. 2014/2015.

Berdasarkan selisih rata-rata hasil postes dan pretes kelas eksperimen dan kelas kontrol, dapat ditarik kesimpulan bahwa peningkatan kompetensi pengetahuan siswa yang dibelajarkan dengan model PBM pada kelas eksperimen lebih rendah dari peningkatan kompetensi pengetahuan siswa yang dibelajarkan dengan pembelajaran PBM pada kelas kontrol. Peningkatan kompetensi pengetahuan kelas eksperimen berdasarkan selisih rata-rata postes dan pretesyaitu 60,78 sedangkan peningkatan kompetensi pengetahuan kelas kontrol yaitu sebesar 62,65. Hal ini dapat dikarenakan kurang efektifnya pelaksanaan pembelajaran yang diajarkan dengan model PBM berbantuan macromedia flash, juga dapat dikarenakan siswa yang masih baru dengan model pembelajaran PBM berbantuan macromedia flash sehingga siswa masih merasa kurang nyaman, didukung oleh sarana yaitu proyektor yang terbatas sehingga harus berpindah kelas saat belajar dengan menggunakan media pembelajaran yang juga mengurangi waktu pembelajaran.

Nilai rata-rata $n$-gain siswa yang dibelajarkan dengan model PBM lebih besar dari nilai rata-rata $n$-gain kelas yang dibelajarkan dengan pembelajaran konvensional. Nilai ratarata $n$-gain siswa yang dibelajarkan dengan model PBM sebesar 0,78dengan predikat peningkatan kompetensi tinggi atau $78 \%$ materi diserap, sedangkan nilai rata-rata $n$-gain siswa yang dibelajarkan dengan pembelajaran konvensional adalah sebesar 0,73 atau $73 \%$ materi diserap dengan predikat peningkatan kompetensi tinggi.

Keadaan di atas sejalan dengan beberapa hasil penelitian terdahulu yang menggunakan model pembelajaran berbasis masalah, diantaranya Sihotang (2014) diperoleh nilai rata-rata pretes kelas eksperimen sebesar 43,81 dan nilai rata-rata postes sebesar 80,05. Pada kelas kontrol diperoleh nilai rata-rata pretes siswa sebesar 44,05 dan nilai rata-rata postes sebesar 68,81 .

Peneliti selanjutnya Situmorang (2014) diperoleh nilai rata-rata pretes kelas eksperimen sebesar 20,45 dan nilai rata-rata postes sebesar 52,65 . Pada kelas kontrol diperoleh nilai ratarata pretes siswa sebesar 19,29 dan nilai rata-rata postes sebesar 47,55. Kelemahan dari kedua peneliti tersebut adalah tidak menggunakan media pembelajaran.

Adanya perbedaan hasil belajar ranah kognitif tersebut disebabkan oleh kelebihan model pembelajaran berbasis masalah yang salah satunya pembelajaran berdasarkan masalah merupakan teknik yang cukup bagus 
untuk lebih memahami isi pelajaran dan membantu siswa bagaimana mentransfer pengetahuan mereka untuk memahami masalah dalam kehidupan nyata.

Kelas Eksperimen yang diajarkan dengan model PBM dengan bantuan media macromedia flash dengan menggunakan Infokus yang tentunya akan membuat minat belajar mereka akan meningkat selain itu mereka juga dituntun berpikir secara kreatif. Selain itu siswa juga akan masuk ke fase dimana mereka akan bekerja sama dalam kelompok kecil yang mempertemukan mereka dengan beberapa teman untuk melaksanakan kegiatan eksperimen dan diskusi. Hal ini sangat baik, selain meningkatkan interaksi sosial, mereka juga dituntut untuk mandiri dan kreatif dalam melaksanakan kegitan eksperimen dalam LKS (Lembar Kerja Siswa) menggunakan alat dan bahan yang sudah disediakan. Eksperimen tersebut memudahkan mereka untuk melihat dengan langsung bagaimana aplikasi materi yang sedang diajarkan.

Berdasarkan penilaian hasil belajar ranah afektif siswa pada kelas eksperimen dan kelas kontrol menunjukkan adanya perbedaan. Dapat dilihat dari hasil rata-rata pengamatan afektif siswa di pertemuan pertama hingga pertemuan ketiga secara berurutan $66,67,83,46$, dan 92,84 dengan kategori masing-masing pertemuan adalah sama, yakni afektif kurang baik, baik dan sangat baik. Sikap siswa kelas kontrol selama proses pembelajaran menunjukkan sikap yang kategorinya kurang baik, cukup baik dan baik, dengan hasil pengamatan rata-rata afektif siswa di pertemuan pertama sampai dengan pertemuan ketiga secara berurutan sebesar 59,11, 75,13, dan 85,42. Menurut Sudjana (2005) kondisi dan karakteristik siswa merupakan ciri dari hasil belajar ranah afektif dalam hal kemauannya untuk menerima pelajaran dari guru, hasratnya untuk bertanya kepada guru dan penghargaannya terhadap guru itu sendiri.

Penilaian kinerja siswa atau psikomotorik kelas eksperimenyaitu dengan rata-rata 22,05, 52,95 dan 76,39 untuk pertemuan perrama hingga pertemuan ketiga dengan kategori kurang baik dan baik. Kelas kontrol tidak memiliki penilaian kerja, hasil belajar dan afektif siswa, karena pada kelas kontrol tidak ada melakukan eksperimen.

Melihat proses pelaksanaan penelitian secara keseluruhan, peneliti menemukan berbagai kekurangan dalam pelaksanaannya yang membuat ketidakmaksimalan pada hasil penelitian. Seperti saat memberikan materi dengan menggunakan media macromedia flash waktu pelajaran terpotong sebab harus pindah ke ruangan yang memiliki infokus. Selain itu ada pemakaian waktu dari jam pelajaran sebelumnya, akhirnya saat pembelajaran berlangsung waktu masih kurang dari $2 \times 45$ menit, sehingga pembelajaran menjadi tidak maksimal.

\section{KESIMPULAN DAN SARAN Kesimpulan}

Berdasarkan hasil penelitian yang diperoleh maka dapat disimpulkan bahwa nilai rata-rata hasil belajar siswa yang diajarkan dengan model pembelajaran berbasis masalah berbantuan macromedia flash yaitu 83,75 , dan nilai rata-rata hasil belajar siswa yang diajarkan dengan model pembelajaran konvensional 77,81.

Berdasarkan hasil perhitungan uji t diperoleh bahwa 2,81> 1,67 yang berarti ada pengaruh model pembelajaran berbasis masalah berbantuan macromedia flash yang signifikan terhadap hasil belajar siswa pada materi fluida dinamis . Penilaian sikap serta keterampilan siswa yang dikembangkan dari model pembelajaran berbasis masalah memberi informasi bahwa dapat meningkatkan keaktifan siswa dalam 
proses pembelajaran ditinjau dari hasil dengan kategori rata-rata afektif serta psikomotorik di setiap pertemuan.

\section{Saran}

Saran yang dapat peneliti ajukan berdasarkan pembahasan yakni untuk peneliti selanjutnya diharapkan lebih mengoptimalkan pengelolaan kelas khususnya pada saat diskusi berlangsung agartidak terjadi kegaduhan-kegaduhan di dalam kelas dan bagi guru dan calon guru, jika menggunakan media supaya dapat memaksimalkan waktu yang ada agar seluruh fase dapat dilaksanakan sehingga kompetensi yang diharapkan dapat tercapai.

\section{Referensi}

Arends,R.I., (2012), Learning to TeachNinth Edition, New York, McGraw Hill.

Arikunto,S., (2012), Dasar-Dasar Evaluasi Pendidikan, Bumi Aksara, Jakarta.

Hake, R.R. 2002. Lessons from the Physics EducationReform Effort. Journal of Conservation Ecology, 5(2):

http://www.consecol.org/vol5/iss2/a rt28 [Diakses pada 09/02/15].

Hermanto, (2013), Pengaruh Model Pembelajaran Berbasis Masalah (Problem Based Learning) Terhadap Hasil Belajar Siswa Pada Materi Pokok Listrik Dinamis Kelas X Semester II SMA N 1 Sei Bingai T.P. 2012/2013, Skripsi. Medan, FMIPA Unimed.

Mutia, A., (2015), Pengaruh Model Pembelajaran Berbasis Masalah Berbantuan Macromedia Flash Terhadap Hasil Belajar Siswa Kelas XI SMA St. Yoseph Medan T.P 2014/2015, Laporan Penelitian Terdahulu, Tidak dipublikasi.

Pohan, (2013), Pengaruh Model Pembelajaran Berbasis Masalah (Problem Based Learning) Terhadap Hasil Belajar Siswa
Pada Materi Pokok Listrik Dinamis Kelas IX SMP N 5 Pematang Siantar T.P. 2012/2013, Skripsi, Medan, FMIPA Unimed.

Selcuk, Selzgin\&Gamze, 2010, The Effect of Problem Based Learning of Pre-servivce, Achievement, Approaches and Attitudes Towards Learning Physics, International Journal of The Physical Sciences, Vol 5 (6):13.

Sanjaya, W., (2011), Strategi Pembelajaran Berorientasi Standar Proses Pendidikan, Prenada Media Grup, Jakarta.

Sihotang, S., (2014), Pengaruh Model Problem Based Learning terhadap Hasil Belajar Siswa pada Materi Kalor di Kelas X Semester II SMA N 02 Pematangsiantar T.P 2013/2014, Skripsi, Medan, FMIPA Unimed.

Situmorang, R., (2014), Pengaruh Model Pembelajaran Berdasarkan MasalahTerhadap Hasil Belajar Siswa Pada Materi Pokok Listrik Dinamis Di Kelas X SMARK DeliMurni Deli Tua T.P 2013/2014, Skripsi, Medan, FMIPA Unimed.

Trianto, (2011),Mendesain Model Pembelajaran Inovatif - Progresif, Kencana, Jakarta. 